\title{
Plural Approaches as a Tool for Galician Studies at the Brazilian University: Didactic Experiences in the UFPR Letters Course
}

\author{
Sweder Souza \\ Post-Graduate Program of Letters, Federal University of Paraná \\ Rua General Carneiro, 460, $10^{\circ}$ andar - sala 1018/1019, Curitiba, Paraná, PR, Brazil \\ Tel: 55-41-99765-6322Ｅ-mail: swedersouza@gmail.com
}

Francisco Javier Calvo del Olmo

Post-Graduate Program of Letters, Federal University of Paraná Rua General Carneiro, 460, $10^{\circ}$ andar - sala 1018/1019, Curitiba, Paraná, PR, Brazil

Tel: 55-41-99689-8502_E-mail: franciscoctl.ctl@gmail.com

\begin{abstract}
Karine Marielly Rocha da Cunha
Modern Foreign Letters Department, Federal University of Paraná

Rua General Carneiro, 460, $9^{\circ}$ andar, Curitiba, Paraná, PR, Brazil

Tel: 55-41-99560-9995Ｅ-mail: karinemrc@hotmail.com
\end{abstract}

Received: February 10, 2020

doi:10.5296/elr.v6i1.16826
Accepted: April 10, 2020 Published: April 11, 2020

URL: https://doi.org/10.5296/elr.v6i1.16826

\begin{abstract}
Even today, Galician Studies are (almost) absent in the Brazilian academic landscape. Paradoxical fact, since the role of Galicia and the Galician language are essential for the understanding of the history and the present day of the Portuguese language (Lagares \& Monteagudo, 2012). Thus, to minimally fill this gap, we have been working, since 2014, in three optional disciplines where this content is examined in a specific way within the theoretical and methodological framework of the Plural Approaches (Candelier, 2007). The
\end{abstract}


subjects of 30 hours each are: Intercomprehension in Romance Languages; Typology of Romance Languages and Introduction to Galician Language and Culture. The latter addresses the argument in a more tangential way. In this text we describe how work is carried out in the discipline of Introduction to Galician Language and Culture, which can serve as inspiration for other institutions that want to develop similar work.

Keywords: Galician studies, Romance languages, Intercomprehension, Sociolinguistics

\section{Introduction}

We start from the observation that Galician Studies are practically absent from the current Brazilian academic landscape (Note 1). This fact seems to us to be enormously paradoxical since the role of Galicia and the Galician language are essential for a complete understanding of both the process of historical formation of the Portuguese language and the actuality of non-standard varieties of Brazilian Portuguese (Lagares \& Monteagudo, 2012). From examining this gap, we decided to create a set of new optional subjects that would bring this content to the classroom and thus expand the training of students in the Course of Letters at the Federal University of Paraná (UFPR). Thus, in 2014, Intercomprehension in Romance Languages was given for the first time (code HE1103) and later, in 2016-2017, the other two started: Introduction to Galician Language and Culture (code HE1112) and Types of Romance Languages (code HE1094).

The link between these three disciplines is justified by the integrated work with languages close to Portuguese, which provide a broader linguistic training for students of Letters. The content of these options also allows rethinking the categories of foreign language and mother tongue (identified in the Brazilian context with Portuguese), which are generally seen as tight, as well as the relationships between hegemonic languages and non-hegemonic, minorized and/or minority interests. We understand that these approaches develop and value the linguistic and cultural repertoires of students and, at the same time, problematize these aspects from a critical perspective. Likewise, the set of these three disciplines is inherent to the theoretical and methodological framework of plural approaches (Candelier et al., 2007) understood as didactic approaches that use teaching and learning activities involving more than one language and/or culture. These approaches propose to students the passage and circulation between languages and cultures, giving new meaning to teaching and learning inside and outside the university environment.

In the Introduction to Galician Language and Culture classes (Note 2), the main focus of this work, students are exposed to reading texts written in Galician, mainly from the 19th and 20th centuries - among them the one by Carreiro (2012), of which we will talk more forward. There are also oral inputs of different types, such as videos, shorts and narratives (Chamorro, Da Silva, \& Nunez, 2008). Such materials aim to explore the proximity and contrasts of this language with Brazilian Portuguese (BP), its phonetic, morphological, syntactic, lexical and orthographic correspondences (Real Academia Galega, 2003). Likewise, the sociolinguistic situation of Galician, the conflicts derived from diglossia with Castilian and the processes of hybridization (castrapo), presented by Monteagudo (1999), are topics of debate in the classes bringing a discussion that, in a certain way, can be compared to the linguistic prejudice that 
exists in Brazil. Students are invited to reflect on these issues and to express their critical position through forms and didactic activities.

In the following pages, we will briefly address the Galician language as an object of study; the context of this discipline at UFPR; the activities carried out and the role of Galician Studies in academic training and in studies of BP, the mother tongue of our students. The experiences reported here can be taken as precedents for those Higher Education Institutions that consider it pertinent to include such training in the curriculum of their courses, thus aiming at the critical study of BP that recognizes in Galician a kind of alterego.

\section{Galician and Portuguese: Two Languages Separated by History}

There are eight countries that have Portuguese as their mother tongue, official and/or administrative: Angola, Brazil, Cape Verde, Guinea Bissau, Equatorial Guinea, Mozambique, Portugal, São Tomé and Príncipe and East Timor. In addition to them, there are regions that belong to other countries, but with which we share or shared the language and some parts of our history such as Macau. In this global context, do they speak or speak Portuguese, their varieties or Creoles, "Galicia, Casamansa (in Senegal), Ilha de Ano Bom, Ajudá (in Benin), Goa, Damão, Diu, Mangalor, Mahé, Fort Cochim, Tellicherry, Chaul, Korlai, Coromandel (Cristovão, 2005, p. 654)". We see that Galicia opens the list of these regions, having a central role in the origins and in the conformation of the Romanesque varieties that constitute Portuguese.

In fact, Galician is a Romance language, that is, formed from the contact of the so-called vulgar Latin with the (probably Celtic) languages spoken in the region that configured the Roman province of Gallaecia (Galecia) and that acted as a substrate.

For this training and “(...) a esse respeito, é interessante atentar para as palavras de Esperança Cardeira, autora portuguesa de um livro sobre a história da sua língua: À entrada do ano mil, no Noroeste peninsular, a Galécia Magna, uma região que se estendia da Galiza a Aveiro abarcando, ainda, uma faixa das Astúrias, delimitava já um romance com contornos peculiares. (...) Não é ainda língua portuguesa. (...) Antes de Portugal, antes do Português, no limiar do século X, já estava constituído um romance(...) (Bagno, 2017, pp. 143-145)”.

However, the structural origin shared between Galician and Portuguese does not mean that the two varieties are one and the same language today, because in addition to structural issues, the condition of languages is linked to social, political, symbolic and cultural factors. In this sense, "[Unha] lingua é unha noción social e político-institucional, a súa existencia e "autonomía lingüística" non dependen automaticamente da maior ou menor distancia lingüística coas linguas veciñas, nin sequera da súa maior ou menor cohesión interna, pois a realidade lingüística demostra que na maior parte dos casos non hai fronteiras precisas entre variedades faladas en países veciños (Álvarez \& Xove, 2002, p. 13)”.

Galician is, then, the proper language of Galicia, co-official together with Castilian since 1981, and regulated by the Royal Academy of the Galician Language (RAG). Despite the process of minorization suffered for several centuries, Galician remains the majority language in its territory. It is worth remembering that Galicia - whose name sometimes appears spelled 
as Galicia - is the continuation of ancient Gallaecia, which also comprised the territory located south of the Douro River, today northern Portugal. Galicia is today an Autonomous Community within the Spanish State, integrated by the provinces of Lugo, Ourense, A Coruña and Pontevedra, which borders Portugal, Asturias and the provinces of León and Zamora. The following map allows you to view these territories.

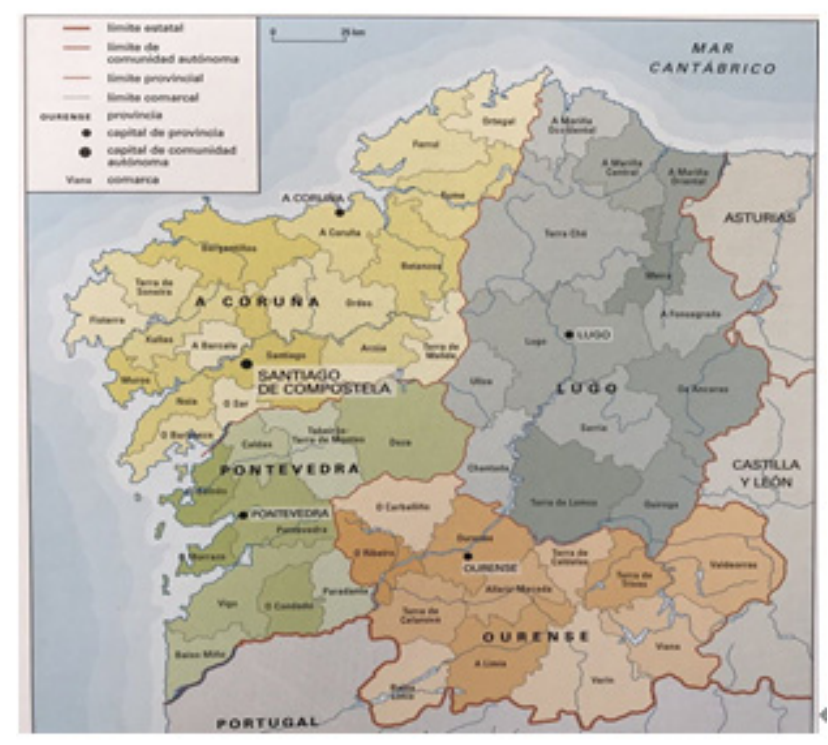

Image I. Political Map of Galicia

SOURCE: Google Images, 2019.

The Romans marked the limits of Gallaecia to the east and also to the south of the Douro. In this sense, there is a shared origin that serves as a historical and social basis for Galician and Portuguese. There are features that characterize the two languages equally within the Romanesque family, even without losing sight of the fact that they are two different languages. Thus, the political frontier between Galicia, belonging to Spain, and Portugal known locally as Raia - was forming as a linguistic frontier, since the varieties spoken on each side followed the dynamics proper to their historical context. Galician can be characterized by direct contact with Castilian or Spanish, the preservation of elements present in the medieval period and the dialectization in several words as a consequence of the absence of an educated norm for more than three centuries. In the 80 s of the last century, RAG had to establish a norm that surpassed archaisms, dialectalisms and Castilisms to make the Galician language a modern cultural vehicle.

The Portuguese establishes their own contacts with the central and southern culture of the Iberian Peninsula. And, from the 15th century onwards, Portugal undertook an overseas expansion in the context of an imperialist project that will lead it to occupy Brazil and several coastal regions in Africa and Asia.

The variants of Northern Portugal, more similar to Galician, are considered as archaic or rural by the grammarians of Lisbon. On the separation of Galician and Portuguese, “(...) é 


\section{Macrothink

interessante, a este respeito, analisar a maneira como os falares galegos são percebidos e julgados pelos portugueses. Desde o século XVI o galego é sentido, ao mesmo tempo, como arcaico e provincial. A personagem do galego constitui até o século XIX uma das figuras tradicionais do teatro popular: trata-se do galego de Lisboa, que exercia as profissões de carregador e de aguadeiro. Caracteriza-se pela linguagem, cujas particularidades acentuam, até à caricatura, alguns traços próprios dos falares portugueses do extremo norte. É assim que o galego, que nas origens da língua tanto contribuiu para definir a norma literária, veio a encontrar-se no pólo oposto desta mesma norma. A rusticidade da Galícia opõe-se, agora, à urbanidade de Lisboa (Teyssier, 2007, p. 34)".

However, intercomprehension between Galician and Portuguese speakers - whether European, Brazilian or African - remains possible in everyday communicative situations. The writer Daniel Rodríguez Castelão (1886-1950), one of the founders of Galician nationalism, politician and cartoonist, illustrated this contact situation in a cartoon that continues today. In the image you can see an old man sitting with a boy on the banks of the Minho River that separates Galicia from Portugal, the text below presents the dialogue between them, a question that the grandson poses to his grandfather.

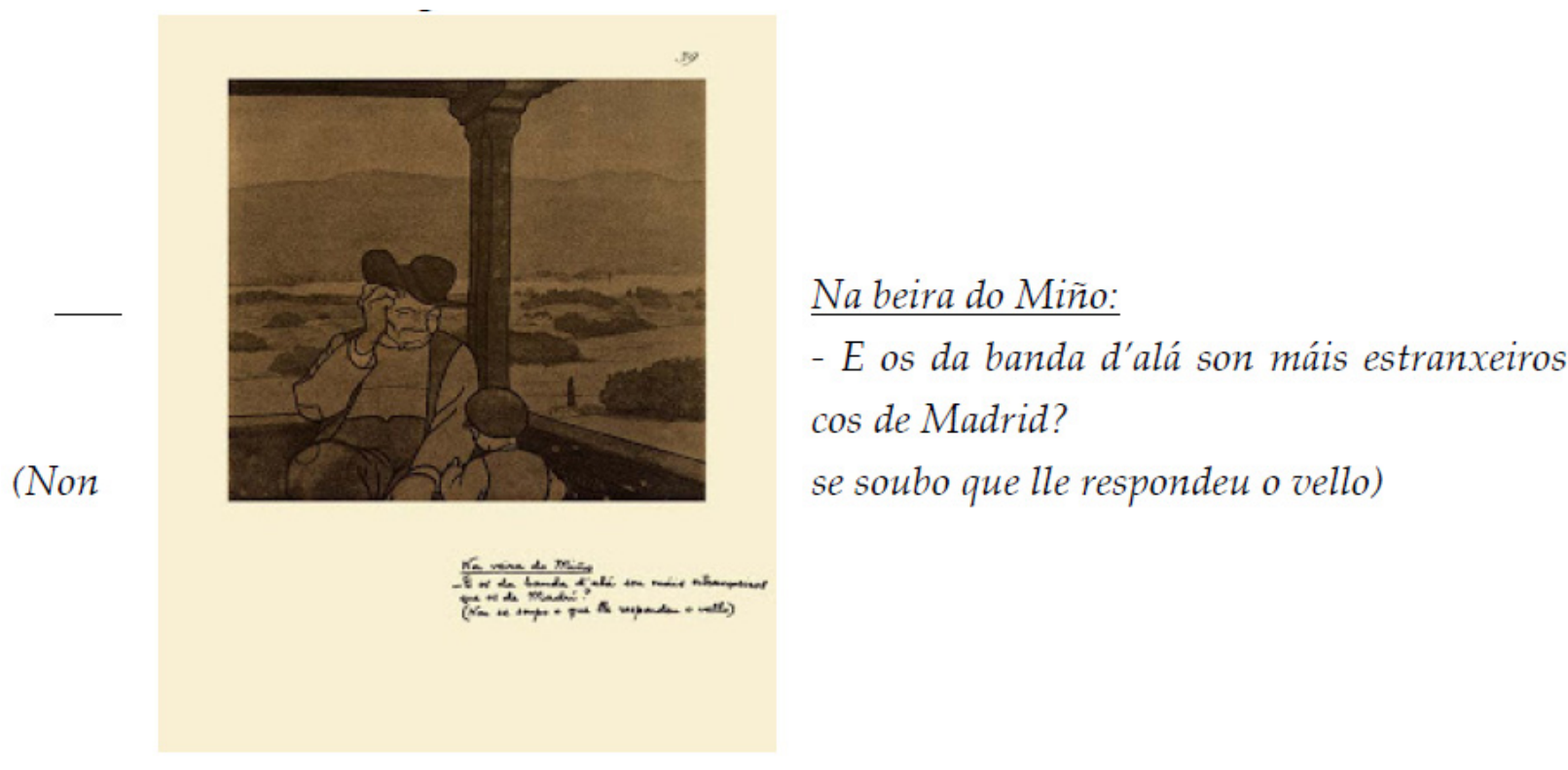

Image II. Illustration of Castelão

SOURCE: Google Images, 2019.

\section{Galician in the UFPR Context}

Hundreds of Galician migrants arrived in Brazil and settled in the city of Curitiba, capital of Paraná, between the second half of the 19th century and the first decades of the 20th century. Today there are associations like Casa da Galiza, which brings together the immigrant community and their descendants and also the dance group Aires Galegos. Despite the presence of this community in our social environment, Galician Studies were practically 
absent in UFPR's hundred years of history (Olmo, 2015).

UFPR is a free public federal university with a community of approximately 2,400 professors and 50,000 students distributed in undergraduate and graduate courses. As a center of excellence, UFPR regularly appears in several international rankings of the best Higher Education Institutions in Latin America. In recent years, new campuses have been opened in inland cities, such as Matinhos, Palotina, Pontal and Jandaia do Sul. In this general context, the disciplines mentioned in the introduction to this text are linked to the Department of Modern Foreign Letters (DELEM) which, together with the Department of Literature and Linguistics (DELLIN) and the Department of Polish, German and Classical Letters (DEPAC), attend the Bachelor's and Bachelor's degrees in Portuguese, German, Spanish, French, Greek, English, Italian, Japanese, Latin and Polish.

The optional subject of Introduction to the Galician Language and Culture places the objective of its menu in presenting the Galician language in its historical and social context, as well as an overview of its artistic, cultural and literary manifestations. Thus, the objective is to prioritize the issues that allow to establish a network of contact and dialogue between the Galician language and the historical formation of the Portuguese language as varieties of the same linguistic system, but understanding that they are two different languages. Consequently, the program is based on the tripod of language, literature and culture. Thus, subjects related to the Galician language are first studied, with an emphasis on intercomprehension and its contrasts within the Romance language family. Then, some works and authors, mainly from the 19th and 20th centuries, are examined. Finally, cultural aspects related to music, geography and Galician rites and traditions are worked on.

The course lasts 30 hours, equivalent to 2 credits, distributed in meetings of 2 hours per week, concentrated in one day. The program covered in the last edition of the discipline (2019.2), was as follows:

\section{Course Schedule}

THEME 1: Galician in Lusophony: history and current events.

THEME 2: Galician and Brazilian Portuguese: intercomprehension and contrasts.

THEME 3: Social history of the Galician language.

THEME 4: Bilingualism, diglossia and linguistic policy.

THEME 5: Identity and linguistic conflicts.

THEME 6: Introduction to Galician Literature.

THEME 7: Rosalía de Castro, Rexurdimento and Irmandades da Fala.

THEME 8: Daniel Manuel Rodríguez Castelao : cartoonist, politician and writer.

THEME 9: Narrative and poetry in the second half of the 20th century.

THEME 10: Music, visual arts and contemporary cultural events. 


\section{Macrothink}

THEME 11: Geography: cities, rural and coastal world.

THEME 12: Rites, mythology and traditions in Galicia.

The scope of the optional is so that students feel comfortable developing their studies in a discipline inherent to their particular and academic goals, in a different way from the mandatory subjects of the course. Therefore, the assessment is made from the themes worked in the classroom and the written activities that students must do and deliver.

In addition, in 2019-02, the semester in which this research was carried out, we received two Galician-Brazilian students, both born in Galicia and coming to Brazil during their childhood, in the migratory wave of the ' 60 s. For them, discipline brought an opportunity to return to their roots, both of whom have already retired.

Below, in Table I, we present as a sample the numbers of enrolled and approved students since their first offer, in 2016.2, until the moment we wrote these pages. We would like to draw your attention to the regularity of the offer: once a year.

Table 1. Enrolled and Approved Students (who completed the course)

\begin{tabular}{ll}
\hline YEAR-SEMSTRER & GALICIAN LANGUAGE AND CULTURE \\
\hline Feb-16 & enrolled: 21 ; approved: 12 \\
Jan-17 & enrolled: 17 ; approved: 10 \\
Feb-17 & not offered \\
Jan-18 & enrolled: 10 ; approved: 7 \\
Feb-18 & not offered \\
Jan-19 & not offered \\
Feb-19 & enrolled: 17 ; approved: 12 \\
Total & enrolled: 65 ; approved: 41 \\
\hline
\end{tabular}

SOURCE: authors, 2019 ( the portal daptado UFPR teacher )

We must clarify that the differences between registered and approved students derive mainly from that students can lock the discipline in the first weeks of the semester. Some other failures were caused by absences or non-delivery of work. The approved number, 41, represents the number of students who completed the workload and completed the training.

\section{Activities in the Introdution to Galician Language and Culture classes}

The first written work of students takes place in relation to the book History of Language Galician, by Pepe Carneiro, seen in the following image: 


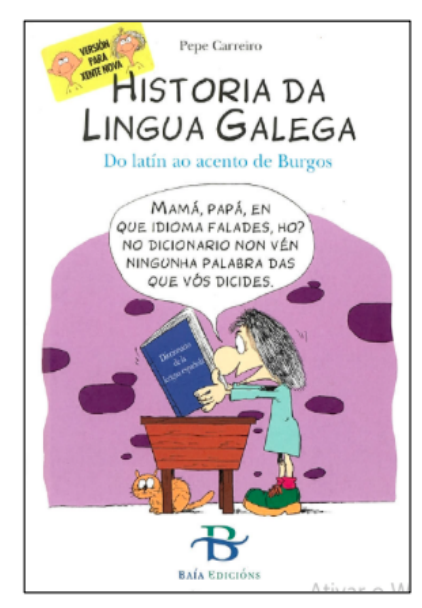

Image III. Book by Pepe Carneiro

SOURCE: Google Images, 2019.

The orientation for this first activity is: "Read the book "History of the Galician Language the Latin the accent Burgos" and make a summary (one to two lines) on each topic presented (for exam ple with the titles in bold at the beginning of the page, summarize each); draw considerations about the Galician Language in relation to the Portuguese Language (or other languages) from a lexical, morphological and syntactic point of view, trying to identify rules of correspondence. For example, from the orthographic point of view it can be said that when the letter "X" appears in such a point in a Galician word, in Portuguese we have the letter "Y" and so on. From a lexical point of view, it would be interesting to list, when possible, the false cognates found in the book, in relation to Portuguese. If necessary, this is the link to consult the Dictionary of the Royal Galician Academy: https://academia.gal/dicionario".

This first reading allows working on the written understanding of Galician; become aware of its orthographic, morphological and lexical peculiarities; dig up shared historical relationships; and getting closer to the sociolinguistic reality of the Galician language today. All of this provides a solid basis for addressing the themes described in the program

The second activity is part of a video lecture in Galician, at that time the students had contact with several written texts and our interest as teachers is directed towards listening. This video lecture presents quantitative and qualitative aspects in the intergenerational transmission of Galician. Each speaker uses very different forms of Galician: Xaquin Loredo, presents models more influenced by Castilian and linked to the uses of so-called neo-speakers, while Valentina Formoso is pale-speaker, that is, she speaks Galician as a language transmitted in the family, with a high degree of authenticity. 


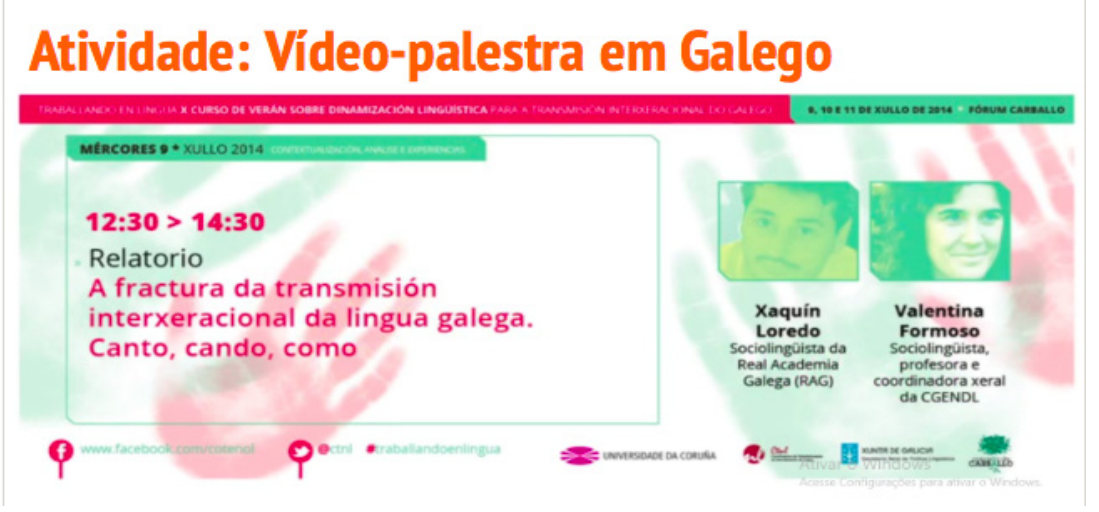

Image IV. Second Activity

SOURCE: Youtube, 2019.

The guidelines for the activity are: "Watch the video "The Fracture of the Intergenerational Transmission of the Galician Language" (Note 3). Researcher Xaquín Loredo and Galician and Portuguese teacher Valentina Formoso take part in it. The first speaker presents quantitative data and the second qualitative data on the transmission of the language. It is interesting to note that Xaquín has the accent of someone who learned Galician, but that it is not his mother tongue (speaker). Valentina, in turn, speaks a Galician with a high degree of "swelling". After watching the video, each student will write a short article (maximum length of a page), where they explain their point of view on the subject, dialoguing with the data presented by the Researchers and bringing up the fundamental points of their speeches".

In this way we finish the part dedicated to the language within the discipline. Within the themes of programming dedicated to literature, we present the third activity that asks to prepare a summary based on the reading of a literary text to be chosen by the students. Here we reproduce the instructions for the activity: "Choose one of the two texts to read: Casa de Merlín, by Álvaro Cunqueiro or Os Difuntos Falaban Castelan, by Anxel Fole. After reading, make a brief summary of the text content (between 1-2 pages). Obs.: in the text by Anxel Fole, the summary can be complemented with information / comparisons of the short film of the same name (Note 4). After the summary, make a comparative overview about cultural aspects of the time, linguistic, social, political etc., to establish relationships of the story with some of the contexts seen in the classes".

The last task requested is a Final Work that tries to answer the following question: "Everything a Brazilian should know about Galicia". Students should develop their creativity and bring the information they deem necessary, regarding history, language, geography, tourist attractions, gastronomy, artistic-literary movements, etc. reviewing notes and materials that worked throughout the semester.

\section{Conclusion}

The approach to the Galician language and culture allows the critical study of PB, which contributes to the linguistic formation of Brazilian citizenship, since it is part of the history 
and the language of the people who live here. Many linguistic phenomena, migratory processes, narratives and popular traditions and countless other socio-historical facts have parallels between Galicia and Brazil. All of them are justified by the origin of Brazilian Portuguese, but official history has long ignored, and partly continues to ignore, Galician's central role in this path. At this point, it was gratifying to find the ways in which the latent relations between Brazil and Galicia could be integrated into the academic life of the Language Courses.

Since 2013 (Note 5), the combination of several factors allowed a series of activities that began to articulate Galician Studies within the training offered by UFPR. Observing the trajectory of the last years, we consider that we have advanced significantly. We were able to curricularize the subjects and consolidate a constantly increasing student body for which Galician language and culture are not unknown. This movement in favor of the diffusion of Galician is perceived in a positive way as it allows to overcome the divisions between hegemonic and subalternized languages, contributing to the democratization of cultural relations between speakers of Romance languages. However, we are aware that much remains to be done to consolidate the presence of UFPR and Curitiba on the map of Galician Studies in Brazil and on the international scene. Along this path, it will be necessary to rely on contributions from different places that cooperate to achieve shared goals. We highlight here the political authorities of universities and cooperation agencies and also the role of our teaching community and the energy of students. In this sense, we must highlight the importance of training researchers who want to develop their Course Conclusion Papers, dissertations and theses on topics involving the Galician language and culture. The participation of scientific networks with other colleagues at the national and international level is also important, which can result in academic exchanges. In the sum of these wishes, we will be able to make the Galician language and its culture flourish even more in the South of Brazil.

\section{Acknowledgement}

Sweder Souza - This work was carried out with support from CNPq (132442/2019-1) and CAPES (001 - 88882.181006/2018-01), through the Master's Scholarship.

This work is the result of a Communication at the DIPROLing2019 Congress, at the State University of Campinas in October 2019, with its Portuguese version published in the Conference Proceedings.

\section{References}

Álvarez, R., \& Xove, X. (2002). Gramática da Lingua Galega. Vigo: Galáxia.

Bagno, M. (2017). Dicionário Crítico de Sociolinguística. São Paulo: Parábola.

Candelier, M., Camilleri Grima, A., Schroder Sura, A., \& Noguerol. (2007). Framework of References for Pluralistic Approaches to Languages and Cultures. Graz: European Centre for Modern Languages, Council of Europe. Disponível em: https:/carap.ecml.at/. Acesso em: 5 $\operatorname{dez} 2019$.

Carreiro, P. (2012). Historia da Língua Galega. A Coruña: Baía Edicións. 


\section{Macrothink}

Chamorro, M., Da Silva, I., \& Núñez, X. (2008). Aula de Galego. Barcelona: Difusión.

Cristóvão, F. (2005). Dicionário Temático da Lusofonia. Lisboa: Texto Editores.

Lagares, X., \& Monteagudo, H. (2012). Galego e Português Brasileiro. Rio de Janeiro: Eduff.

Monteagudo, H. (1999). História Social da Lingua Galega. Vigo: Galaxia.

Olmo, F. J. C. (2015). Nascem os Estudos Galegos na Universidade Federal do Paraná. Disponível em https:/quilombonoroeste.wordpress.com/tag/estudos-galegos/. Acesso em: 5 $\operatorname{dez} 2019$.

Real Academia Galega. (2019). Normas Ortográficas e Morfolóxicas do Idioma Galego. Disponível em: https://academia.gal/documents/10157/704901/Normas+ortográficas+e+ morfolóxicas + do+idioma+galego.pdf. Acesso em: 5 dez 2019.

Teyssier, P. (2007). História da língua portuguesa. (Tradução de Celso Cunha). São Paulo: Martins Fontes.

Xunta de Galicia. (2019). Lingua Galega. Disponível em https://www.xunta.es/ linguagalega/arquivos/normasrag.pdf Acesso em: 22 nov 2019

\section{Notes}

Note 1. In Brazil, the Federal University of Bahia, the State University of Rio de Janeiro and the University of São Paulo have Galician Study Centers, including active readers. The Fluminense Federal University has a very strong Galician Studies Center. Xunta de Galicia promotes the study and diffusion of Galician in universities in Latin America, Europe and the United States, as can be seen at: https://www.edu.xunta.gal/portal/node/22812

Note 2. Francisco Calvo del Olmo and Karine Marielly Rocha da Cunha while professors UFPR and Sweder Souza, master's student who completed, in the second semester of 2019, his teaching internship in the discipline.

Note 3. vailable in: https://www.youtube.com/watch?v=1XA36sgqfQU.

Note 4. Available in: https://www.youtube.com/watch?v=AGIMx4z5-tQ.

Note 5. In 2013, during the conference cycle entitled Flores do Lácio, one of the conferences was on the Galician language.

\section{Copyright Disclaimer}

Copyright reserved by the author(s).

This article is an open-access article distributed under the terms and conditions of the Creative Commons Attribution license (http://creativecommons.org/licenses/by/3.0/). 